\title{
Preliminary Study on Fish Larvae at Selected Coastal Waters of Sarawak
}

\author{
NORHAKIMI MUHAMAD* \& SITI AKMAR KHADIJAH AB RAHIM \\ Department of Aquatic Science, Faculty of Resource Science and Technology, Universiti Malaysia \\ Sarawak, 94300 Kota Samarahan, Sarawak, Malaysia
}

\begin{abstract}
A survey were carried out from April to November 2012 at five study sites namely Teluk Pandan beach, Rambungan beach, Puteri beach, Sampadi Island and Satang Besar Island, Sarawak. This survey was carried out in order to obtain early documentation of fish larvae at selected coastal waters of Sarawak. Seine net (1 mm mesh size) which was pulled by two persons at intertidal zone; and bridle net ( $0.5 \mathrm{~mm}$ mesh size) that was towed by boat at subtidal zone (Sampadi Island only) were used to collect the samples. A total of 2,562 fish larvae which comprise 25 families were obtained from both sampling methods. A total of 16 families of fish larvae were caught by seine net from the intertidal zone. The same number of families was collected at the subtidal zone of Sampadi Island by bridle net. Ambassidae, Clupeidae, Engraulidae and Gerreidae found to be dominant families in the study sites. Clupeidae and Gerreidae shown a wide larval dispersal area because they were collected at all study sites. These findings seem to indicate that the subtidal zone of Sampadi support more species of fish larvae.
\end{abstract}

Keywords: Composition, distribution, fish larvae, Sarawak

\section{INTRODUCTION}

Fish larvae are the newly hatched fish eggs which also referred to as ichthyoplankton. Most larval fishes tend to occupy the habitat with high food availability, low predation rate and stable ocean condition for growth (Freitas \& Muelbert, 2004). Habitats that fulfil these requirements usually are seagrass beds, estuaries, littoral areas and reef habitats where the water is generally shallow and the larger predators will tend to avoid such environments (Anand \& Pillai, 2005; Ara et al., 2011a; Ara et al., 2011b; Baran, 2002; Breitburg et al., 1995).

The presence of fish larvae can be an indicator of the health of aquatic environment as fish will use this area as the spawning grounds (Chamchang \& Chayakul, 2000; Freitas \& Muelbert, 2004) and suitable for their recruitment (Arkhipov, 2009). Ichthyoplankton survey is a way of generating fisheryindependent stock assessment and key component in understanding function of marine ecosystem (Moser \& Smith, 1993). Knowledge about larval stages including their dispersal and settlement events are important to ensure the

*Corresponding author: norhakimimuhamad@yahoo.com consistent stock recruitment in improving the management of local fisheries (Baran, 2002).

The studies on ichthyoplankton have been conducted worldwide but in Malaysia, this research did not attract much attention to researchers. About 15 years ago, Blaber et al. (1997) studied on composition, distribution and habitat affinities of ichthyoplankton focused on selected estuaries in Sarawak and Sabah. Recently, ichthyoplankton studies were made to compare the larval fish density between seagrass beds and outside of seagrass beds of the Southwestern Johor (Ara et al., 2011a) and feeding habits of Clupeidae larval fishes in the estuary of River Pendas in Johor (Ara et al., 2011b).

The coastal waters of Sarawak are subjected to the influence of many large rivers which transport sediment and nutrients to the coastal areas that will lead to water quality degradation. In addition, anthropogenic activities are increasing with the increment in human population. These could influence the fish larvae community and monitoring their population is crucial in order to maintain the fish stock in natural habitat. Therefore, it is 
timely to obtain current information on species composition and distribution of fish larvae in Sarawak coastal waters. Several locations at the northwest of Sarawak coastal waters were chosen as preliminary research's study sites for fish larvae.

\section{MATERIALS \& METHODS}

One time sampling was carried out at five study sites as plotted in Figure 1. Coordinates readings of each sampling sites were recorded in the Table 1 below. At each sampling station, seine net ( $1 \mathrm{~mm}$ mesh size) were pulled by two persons for about two min (fixed operating time) at intertidal zone. The number of replicates for each station was differed subjected to the condition of the study area as descripted in Table 2. Least replicates taken at Teluk Pandan beach was due to strong wave action while the present of dead logs and concrete rubble at Rambungan beach restricted the area to collect the sample.

A sampling using bridle net $(0.5 \mathrm{~mm}$ mesh size) was also conducted at Sampadi Island on July 2012. The sampling was carried out to find the species composition of fish larvae at subtidal zone. Habitat structures of subtidal zone of Sampadi Island mainly consist of huge rock formation, with coral reef habitats and seaweed at certain part surrounding the island.
Bridle net was towed in oblique manner using a boat at subtidal zone for about $10 \mathrm{~min}$ with increasing speed until it reached 2 knot (maximum speed) surrounding Sampadi Island and this was repeated five times surrounding the island (Mohamad-Norizam \& Ali, 2009). All collected samples were preserved in $10 \%$ buffered formalin in seawater and later transferred into $80 \%$ ethanol upon sorting (Mohamad-Norizam \& Ali, 2009).

The fish larvae were identified up to family level through their morphological characteristics guided with identification books by Jeyaseelan (1998), Leis \& Carson-Ewart (2000) and Ré \& Meneses (2009). 'Unidentified larvae' was used for the larvae that were damaged and hard to distinguish their characteristics. The common names of possible local fishes that belong to those families were checked using the guide book published by Department of Fisheries Malaysia (2009). Then, the fish larvae were counted and catch per unit effort $(\mathrm{CPUE}=$ number of individuals per replicates) was calculated to standardize the data (Marchetti \& Moyle, 2000). The calculation was used for both sampling methods to make it comparable between each other especially for Sampadi Island. The replicates were measured as the number of sample taken for each study site.

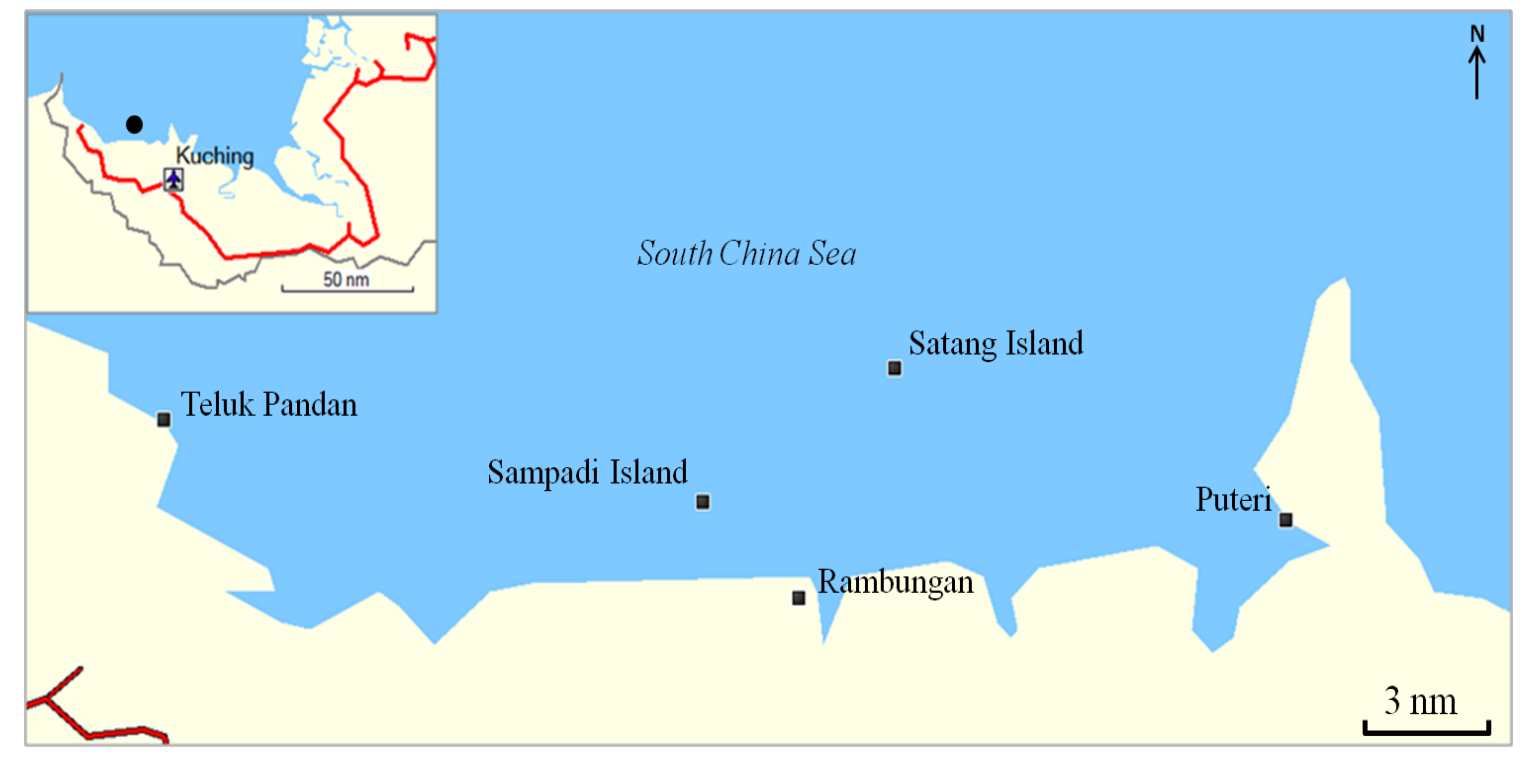

Figure 1. This survey was conducted at the northwest of Sarawak (marked by the dark circle) involving five study sites as indicated by the dark squares. 
Table 1. List of study sites and its coordinates.

\begin{tabular}{cc}
\hline Study Site & Coordinates \\
\hline Teluk Pandan beach & $\mathrm{N} 01^{\circ} 45^{\prime} 43.9^{\prime \prime} \mathrm{E} 109^{\circ} 52^{\prime} 14.3^{\prime \prime}$ \\
Rambungan beach & $\mathrm{N} 01^{\circ} 41^{\prime} 50.6^{\prime \prime} \mathrm{E} 110^{\circ} 07^{\prime} 22.8^{\prime \prime}$ \\
Puteri beach & $\mathrm{N} 01^{\circ} 43^{\prime} 32.3^{\prime \prime} \mathrm{E} 110^{\circ} 18^{\prime} 56.0^{\prime \prime}$ \\
Satang Island & $\mathrm{N} 01^{\circ} 46^{\prime} 49.7^{\prime \prime} \mathrm{E} 110^{\circ} 09^{\prime} 52.9^{\prime \prime}$ \\
Sampadi Island & $\mathrm{N} 01^{\circ} 43^{\prime} 55.5^{\prime \prime} \mathrm{E} 110^{\circ} 05^{\prime} 04.8^{\prime \prime}$ \\
\hline
\end{tabular}

Table 2. List of study sites, dates of sample collection, number of replicates for each study site and the description of the site.

\begin{tabular}{|c|c|c|c|}
\hline Study Site & $\begin{array}{c}\text { Date of } \\
\text { Collection }\end{array}$ & $\begin{array}{c}\text { No. of } \\
\text { Replicates }\end{array}$ & Site Description \\
\hline Teluk Pandan beach & April 2012 & 5 & $\begin{array}{l}\text { flat tidal beach; some part covered with rocks; strong } \\
\text { wave action }\end{array}$ \\
\hline Rambungan beach & May 2012 & 5 & $\begin{array}{l}\text { narrow sandy beach with small rocks covered the } \\
\text { floor; dead logs and concrete rubble }\end{array}$ \\
\hline Puteri beach & May 2012 & 7 & sandy-muddy shore; small patch of mangrove trees \\
\hline Satang Island & $\begin{array}{l}\text { September } \\
\quad 2012\end{array}$ & 8 & $\begin{array}{l}\text { small rocks covered the floor; surrounded by coral } \\
\text { reef and seaweed }\end{array}$ \\
\hline Sampadi Island & $\begin{array}{l}\text { November } \\
2012\end{array}$ & 8 & $\begin{array}{l}\text { muddy floor covered with gravels; rocky beach; some } \\
\text { part covered with seagrass beds }\end{array}$ \\
\hline
\end{tabular}

The in-situ water quality parameters were taken at each sampling station of intertidal zone (except Satang Island). Water temperature and dissolved oxygen was recorded using multiprobe (Eu-Tech CyberScan 600 PCD650). Water turbidity and salinity were recorded using turbidity meter (Eu-Tech $\mathrm{TN}-100)$ and salinometer (Milwaukee MA887), respectively. The recorded water quality readings were not further discussed because it is not comparable to each study site due to the differences in time of sampling and number of replicate.

\section{RESULTS \& DISCUSSION}

A total of 2,685 fish larvae were caught in this survey whereby 2,562 fish larvae were collected with seine net (Table 3) and 123 fish larvae collected from bridle net (Table 4). In this survey, a total of 25 families were identified. Common names of possible local fishes following Department of Fisheries Malaysia (2009) that belong to those families are listed in Table 3. Based on both collection methods, 16 families of fish larvae were obtained under both seine net and bridle net (Table 2).
Family composition of fish larvae at intertidal zone of each station were shown in Table 3. Two families namely, Clupeidae and Gerreidae were found at all sampling sites. This suggests that the larvae from these two families are widely dispersed. According to habitat preferences by the adult fishes, species under these two families are mostly reef-associated fishes while certain species living in pelagic area and others are demersal type of fishes (Department of Fisheries Malaysia, 2009).

Satang Island and Sampadi Island showed the highest catch per unit effort (CPUE) compared to other sampling sites (Table 4). These two islands also hold higher fish diversity compared to others. The presence of coral reef and seaweed at Satang Island and coral reef and seagrass beds at Sampadi Island could be the contribution factor to the high fish diversity at both islands. Coral reef and seagrass are known to be the favourable habitat for the larval fishes (Anand \& Pillai, 2005; Ara et al., 2011a; Ara et al., 2011b; Baran, 2002; Breitburg et al., 1995) because abundant of food availability, low predation rate and stable ocean condition for growth (Freitas \& Muelbert, 2004). 
Certain families of fish larvae were caught in abundance in the intertidal area. Clupeidae and Gerreidae contributed high percentage of fish larvae at Teluk Pandan beach comprising $53.33 \%$ and $41.48 \%$, respectively. Rambungan beach and Puteri beach also recorded high percentage of Clupeidae contributing $81.82 \%$ and $70.59 \%$, respectively. Ambassidae $(87.79 \%)$ was the most abundant at Satang Island while Engraulidae was dominant $(81.39 \%)$ at Sampadi Island. Other families were found to have small percentage composition $(0.06 \%$ to $11.76 \%)$ at each site.
Shoaling behaviour in some fishes could be one of the factors that contributed to the abundance of fish larvae of Ambassidae, Clupeidae, Engraulidae and Gerreidae caught. Fish live in shoals because of various reasons such as for feeding activity, mating and safety (Spooner, 1931). Shoaling behaviour also could reduce the predation rate by confusing the predator from detecting the fish (prey) (Partridge, 1982). These reasons could be used by the fish larvae that were caught in abundance at each sampling site.

Table 3. List of family of fish larvae that were collected at all sampling stations with both seine net and bridle net including their common name of possible local fishes belonging to each family. The '+' and '-' symbols indicate the present and absent of fish larvae for each particular family, respectively.

\begin{tabular}{lccl}
\hline Family & Seine Net & Bridle Net & Common Name of Possible Local Fishes \\
\hline Ambassidae & + & + & Glassfish, Glass perch \\
Apogonidae & - & + & Cardinalfish \\
Atherinidae & + & + & Silverside \\
Balistidae & - & + & Triggerfish \\
Blenniidae & + & + & Comb-tooth, Rockskipper \\
Callionymidae & - & + & Dragonet, Mandarin fish \\
Carangidae & + & - & Scad, Trevally, Mackerel, Queenfish \\
Chanidae & + & + & Milkfish \\
Clupeidae & + & + & Sardine, Sardinella, Shad, Herring, Sprat \\
Cynoglossidae & - & + & Tonguesole \\
Engraulidae & + & - & Anchovy, Thryssa \\
Exocoetidae & - & + & Flyingfish \\
Gerreidae & + & + & Silver-biddy, Mojarra \\
Gobiidae & + & + & Goby, Mudskipper \\
Hemiramphidae & + & - & Halfbeak \\
Leiognathidae & + & - & Ponyfish, Slipmouth, Silverbelly \\
Megalopidae & + & - & Ladyfish, Moonfish, Tarpon \\
Monacanthidae & - & + & Filefish, Leatherjacket, Tapefish \\
Mugilidae & + & - & Mullet \\
Myctophidae & - & + & Lantern fish \\
Ptereleotridae & + & - & Goby, Dartfish \\
Scorpaenidae & - & + & Scorpionfish, Stonefish \\
Serranidae & - & + & Grouper, Sea bass, Rockcod \\
Sillaginidae & + & - & Sillago, Whiting \\
Terapontidae & + & - & Perch, Terapon, Grunter \\
Unidentified larvae & + & + & \\
\hline
\end{tabular}


Table 4. Family composition of fish larvae at intertidal zone of each station $(n=$ number of fish larvae for each family; $\%=$ percentage of family of fish larvae at each station).

\begin{tabular}{|c|c|c|c|c|c|c|c|c|c|c|}
\hline \multirow[t]{2}{*}{ Family } & \multicolumn{2}{|c|}{$\begin{array}{c}\text { Teluk Pandan } \\
\text { beach }\end{array}$} & \multicolumn{2}{|c|}{$\begin{array}{c}\text { Rambungan } \\
\text { beach }\end{array}$} & \multicolumn{2}{|c|}{ Puteri beach } & \multicolumn{2}{|c|}{ Satang Island } & \multicolumn{2}{|c|}{$\begin{array}{c}\text { Sampadi } \\
\text { Island }\end{array}$} \\
\hline & $\mathbf{n}$ & $\%$ & $\mathrm{n}$ & $\%$ & $\mathbf{n}$ & $\%$ & $\mathbf{n}$ & $\%$ & $\mathbf{n}$ & $\%$ \\
\hline Ambassidae & 0 & 0.00 & 0 & 0.00 & 0 & 0.00 & 1575 & 87.79 & 1 & 0.25 \\
\hline Atherinidae & 0 & 0.00 & 0 & 0.00 & 0 & 0.00 & 1 & 0.06 & 1 & 0.25 \\
\hline Blenniidae & 0 & 0.00 & 0 & 0.00 & 1 & 0.65 & 1 & 0.06 & 0 & 0.00 \\
\hline Carangidae & 0 & 0.00 & 0 & 0.00 & 0 & 0.00 & 0 & 0.00 & 1 & 0.25 \\
\hline Chanidae & 0 & 0.00 & 0 & 0.00 & 0 & 0.00 & 0 & 0.00 & 3 & 0.74 \\
\hline Clupeidae & 72 & 53.33 & 63 & 81.82 & 108 & 70.59 & 3 & 0.17 & 49 & 12.16 \\
\hline Engraulidae & 1 & 0.74 & 0 & 0.00 & 7 & 4.48 & 0 & 0.00 & 328 & 81.39 \\
\hline Gerreidae & 56 & 41.48 & 5 & 6.49 & 18 & 11.76 & 140 & 7.80 & 8 & 1.99 \\
\hline Gobiidae & 3 & 2.22 & 1 & 1.30 & 0 & 0.00 & 0 & 0.00 & 0 & 0.00 \\
\hline Hemiramphidae & 0 & 0.00 & 0 & 0.00 & 0 & 0.00 & 1 & 0.06 & 0 & 0.00 \\
\hline Leiognathidae & 0 & 0.00 & 0 & 0.00 & 0 & 0.00 & 0 & 0.00 & 5 & 1.24 \\
\hline Megalopidae & 0 & 0.00 & 0 & 0.00 & 0 & 0.00 & 4 & 0.22 & 0 & 0.00 \\
\hline Mugilidae & 0 & 0.00 & 0 & 0.00 & 0 & 0.00 & 10 & 0.56 & 7 & 1.74 \\
\hline Ptereleotridae & 0 & 0.00 & 0 & 0.00 & 0 & 0.00 & 1 & 0.06 & 0 & 0.00 \\
\hline Sillaginidae & 2 & 1.48 & 0 & 0.00 & 9 & 5.88 & 57 & 3.18 & 0 & 0.00 \\
\hline Terapontidae & 0 & 0.00 & 6 & 7.79 & 0 & 0.00 & 1 & 0.06 & 0 & 0.00 \\
\hline $\begin{array}{l}\text { Unidentified } \\
\text { larvae }\end{array}$ & 1 & 0.74 & 2 & 2.60 & 10 & 6.54 & 0 & 0.00 & 0 & 0.00 \\
\hline $\begin{array}{l}\text { Total number of } \\
\text { fish larvae }\end{array}$ & 135 & & 77 & & 153 & & 1794 & & 403 & \\
\hline CPUE & 27.00 & & 15.40 & & 21.86 & & 224.25 & & 50.38 & \\
\hline $\begin{array}{l}\text { Total number of } \\
\text { family }\end{array}$ & 5 & & 4 & & 5 & & 11 & & 9 & \\
\hline
\end{tabular}

At Sampadi Island, a total of 20 families of fish larvae were recorded (Table 5). It was observed that subtidal zone recorded higher number of family (16 families) compared to intertidal zone (nine families) but the number of fish larvae caught at subtidal zone was lesser than intertidal zone. This suggests that, subtidal zone holds high diversity of fish larvae compared to intertidal zone. At the same time, subtidal zone cannot support high number of fish larvae compared to intertidal zone based on the abundant of fish larvae caught.

Possible reason for this outcome could be related to the nature of the fish larvae itself. Based on observation, it was found that the fish larvae that were caught at intertidal zone were relatively larger compared to subtidal zone. Besides, their physical appearances are closed to adult fishes where most of their swimming appendages can be seen clearly (Figure 2a). On the other hand, most fish larvae that were caught at subtidal zone still have unformed mouth, fins and tail (Figure $2 b)$. Therefore, larger fish larvae are capable of finding safety location compared to smaller fish larvae that usually drifting with the water current (Fleischer, 2007).

The recorded temperatures were ranged from 29 to $31^{\circ} \mathrm{C}$ at all four study sites (Figure 3a). Teluk Pandan shows the highest dissolved oxygen recorded $(10.20 \pm 0.10 \mathrm{mg} / \mathrm{l})$ (Figure $3 \mathrm{~b})$. Highest turbidity recorded at Puteri beach $(71.51 \pm 26.91 \mathrm{NTU})$ (Figure 3c). The salinity recorded ranged from 28 to $32 \mathrm{PSU}$ at all study sites (Figure 3d).

The distribution and dispersal of fish larvae could be influenced by several factors such as tidal influenced, water turbidity, spawning time and season as well as feeding habits and food availability. This is because oceanographic and meteorological features are often associated with seasonal patterns of abundance of fish larvae (Hernandez-Miranda et al., 2003) and it can influence feeding and 
transportation of larvae by currents (Freitas \& Muelbert, 2004). Fish larvae of different species and life stage require different environmental factors at any given time (Sameoto, 1984). Thus, a temporal monitoring is required in order to see any changes in either physical or biological factors with time.

Table 5. Abundance of family of fish larvae at intertidal and subtidal zone of Sampadi Island.

\begin{tabular}{|c|c|c|c|c|}
\hline \multirow{2}{*}{ Family } & \multicolumn{2}{|c|}{ Intertidal } & \multicolumn{2}{|c|}{ Subtidal } \\
\hline & $\mathbf{n}$ & $\%$ & n & $\%$ \\
\hline Ambassidae & 1 & 0.25 & 10 & 8.13 \\
\hline Apogonidae & 0 & 0.00 & 15 & 12.20 \\
\hline Atherinidae & 1 & 0.25 & 8 & 6.50 \\
\hline Balistidae & 0 & 0.00 & 1 & 0.81 \\
\hline Blenniidae & 0 & 0.00 & 6 & 4.88 \\
\hline Callionymidae & 0 & 0.00 & 31 & 25.20 \\
\hline Carangidae & 1 & 0.25 & 0 & 0.00 \\
\hline Chanidae & 3 & 0.74 & 4 & 3.25 \\
\hline Clupeidae & 49 & 12.16 & 9 & 7.32 \\
\hline Cynoglossidae & 0 & 0.00 & 2 & 1.63 \\
\hline Engraulidae & 328 & 81.39 & 0 & 0.00 \\
\hline Exocoetidae & 0 & 0.00 & 1 & 0.81 \\
\hline Gerreidae & 8 & 1.99 & 4 & 3.25 \\
\hline Gobiidae & 0 & 0.00 & 15 & 12.20 \\
\hline Leiognathidae & 5 & 1.24 & 0 & 0.00 \\
\hline Monacanthidae & 0 & 0.00 & 3 & 2.44 \\
\hline Mugilidae & 7 & 1.74 & 0 & 0.00 \\
\hline Myctophidae & 0 & 0.00 & 1 & 0.81 \\
\hline Scorpaenidae & 0 & 0.00 & 3 & 2.44 \\
\hline Serranidae & 0 & 0.00 & 8 & 6.50 \\
\hline Unidentified larvae & 0 & 0.00 & 2 & 1.63 \\
\hline Total number of fish larvae & 403 & & 123 & \\
\hline CPUE & 50.38 & & 24.60 & \\
\hline Total number of family & 9 & & 16 & \\
\hline
\end{tabular}

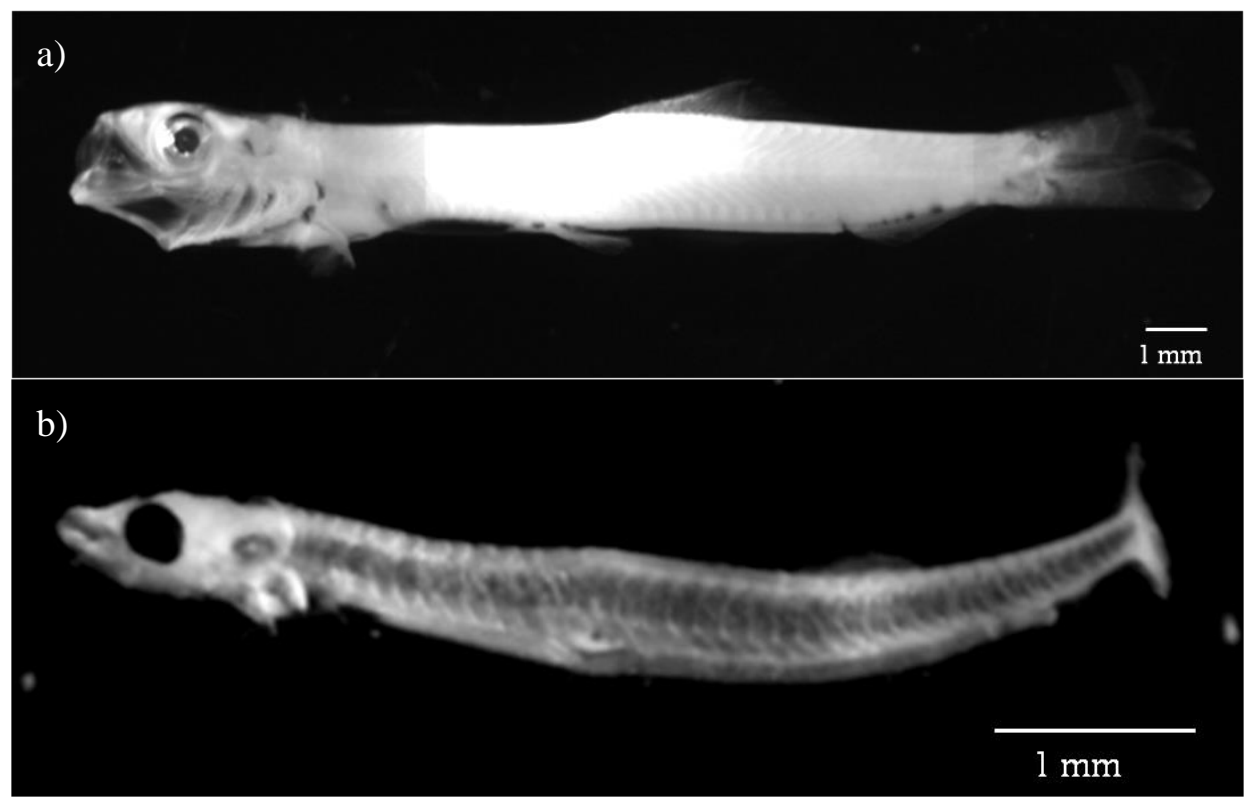

Figure 2. An example of Clupeidae larvae that were caught at Sampadi Island located at: a) intertidal zone: fish larvae almost resemble an adult fish with almost well-developed fins for better swimming ability; b) subtidal zone: fish larvae are relatively small in size with undeveloped fins that make it unable to move freely but rather drifting in the water column. 
a)

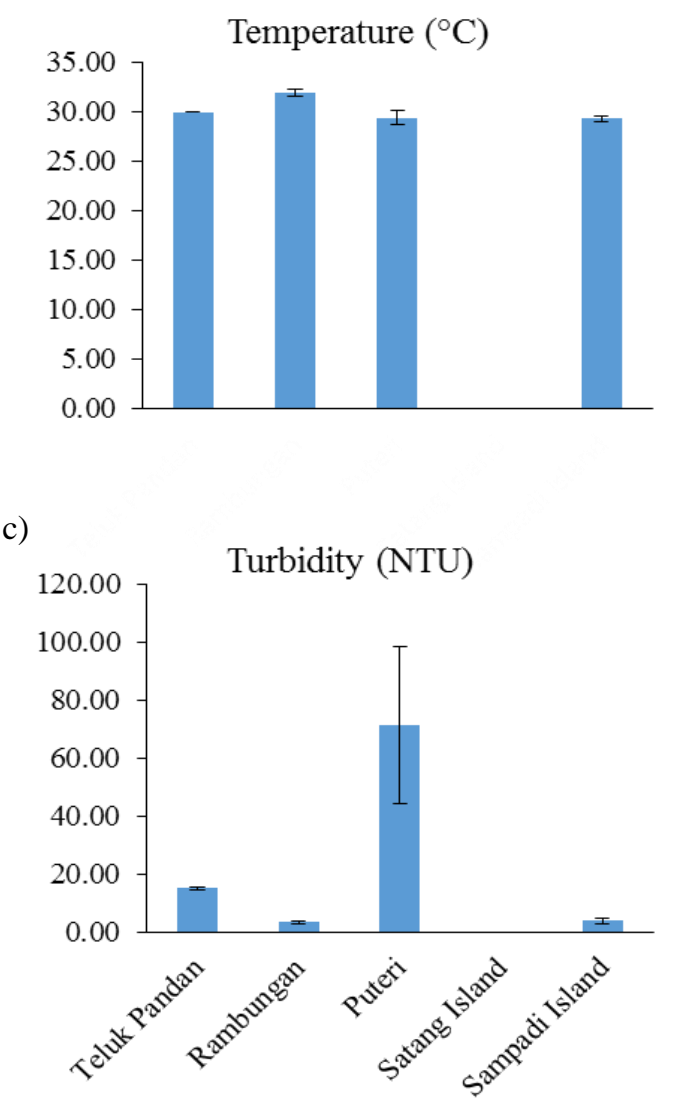

b)

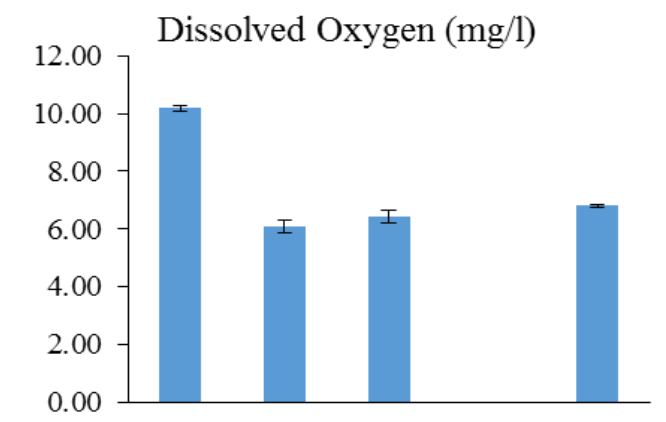

d)

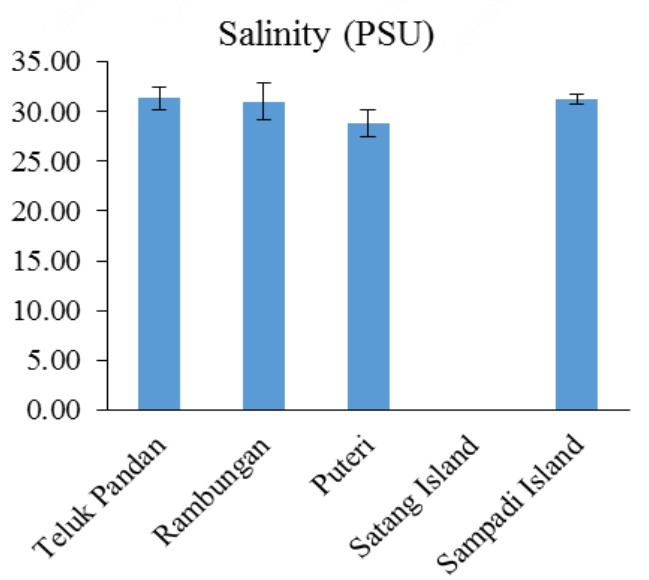

Figure 3. In-situ water quality parameters recorded at each sampling sites namely: a) temperature; b) dissolved oxygen; c) turbidity; d) salinity.

\section{CONCLUSION}

A total of 25 families were identified throughout the study. Some families such as Clupeidae and Gerreidae have a wide larval dispersal in the study area. Shoaling behaviour of fishes resulted in higher number of fish larvae caught for Ambassidae, Clupeidae, Engraulidae and Gerreidae. This short survey shed some scientific information on the biodiversity and distribution of fish larvae at Sarawak coastal waters. Further work need to be done in order to obtain more information for future management of stock fishes in our coastal waters.

\section{ACKNOWLEDGEMENT}

We would like to thank UNIMAS for providing the facilities and logistic supports throughout the study. Special thanks to staffs from Department of Aquatic Science, Faculty of Resource Science and Technology, UNIMAS for helping us during this study.

\section{REFERENCES}

Anand, V.P.E. \& Pillai, N.G.K. (2005). Occurrence of juvenile fishes on the seagrass beds of Kavaratti Atoll, Lakshadweep, India. Indian Journal of Fisheries, 52 (4): 459-467.

Ara, R., Arshad, A., Amin, S.M.N., Daud, S. K., \& Mazlan, A.G. (2011a). Comparison of larval fish density between seagrass beds of the Southwestern Johor, Peninsular Malaysia. Journal of Fisheries and Aquatic Science, 6 (7): 795-801.

Ara, R., Arshad, A., Musa, L., Amin, S.M.N., \& Kuppan, P. (2011b). Feeding habits of larval fishes of the Family Clupeidae (Actinopterygii: Clupeiformes) in the estuary of River Pendas, Johor, Malaysia. Journal of Fisheries and Aquatic Science, 6 (7): 816-821. 
Arkhipov, A.G. (2009). Seasonal and interannual variation of ichthyoplankton off Mauritania. Journal of Ichthyology, 49 (6): 460-468.

Baran, E. (2002). The importance of noncommercial fish. Fisheries and Aquaculture: towards sustainable aquatic living resources management. UNESCO Encyclopedia of Life Support Systems. Oxford: EOLSS Publishers. Pp 2-11.

Blaber, S.J.M., Farmer, M.J., Milton, D.A., Pang, J., Boon-Teck, O., \& Wong, P. (1997). The ichthyoplankton of selected estuaries in Sarawak and Sabah: composition, distribution and habitat affinities. Estuarine, Coastal and Shelf Science, 45 (2): 197-208.

Breitburg, D.L., Palmer, M.A., \& Loher, T. (1995). Larval distributions and spatial patterns of settlement of an oyster reef fish: responses to flow and structure. Marine Ecology Progress Series, 125: 4560.

Chamchang, C. \& Chayakul, R. (2000). Composition, abundance and distribution of ichthyoplankton in the South China Sea, area III: western Philippines. In Proceedings of The 3rd Technical Seminar on Marine Fishery Resources Survey in The South China Sea, Area 3: western Philippines. Southeast Asian Fisheries Development Center (SEAFDEC), Bangkok. Pp148-163.

Department of Fisheries Malaysia (2009). Malaysia. Valid Local Name of Malaysian Marine Fishes. 180 pp.

Fleischer, A.J. (2007). The abundance, distribution and diversity of ichthyoplankton in the Puget Sound estuary and San Juan Islands during early spring. Senior Thesis, University of Washington.

Freitas, D.M. \& Muelbert, J.H. (2004). Ichthyoplankton distribution and abundance off Southeastern and Southern Brazil. Brazilian Archives of Biology and Technology, 47 (4): 601-612.
Hernandez-Miranda, E., Palma, A.T., \& Ojeda, F.P. (2003). Larval fish assemblages in nearshore coastal waters off central Chile: temporal and spatial patterns. Estuarine, Coastal and Shelf Science, 56: 1075-1092.

Jeyaseelan, M.J.P. (1998). Manual of fish eggs and larvae from Asian mangrove waters. France: UNESCO Publishing.

Leis, J.M. \& Carson-Ewart, B.M. (2000). The larvae of Indo-Pacific coastal fishes: an identification guide to marine fish larvae. Leiden: Brill Academic Publishers.

Marchetti, M.P. \& Boyle, P.B. (2000). Spatial and temporal ecology of native and introduced larval fish in Lower Putah Creek, California. Environmental Biology of Fishes, 58(1): 75-87.

Mohamad-Norizam, M. \& Ali, A.B. (2009). Spatial-distribution pattern of fish larvae in the east coast off Pulau Payar Marine Park, Kedah, Malaysia. Journal of Sustainability and Management, 4 (2): 141-145.

Moser, H.G. \& Smith, P.E. (1993). Larval fish assemblages and oceanic boundaries. Bulletin of Marine Science, 53: 283-289.

Partridge, B.L. (1982). Structure and function of fish schools. Scientific American, 246 (6): 114-123.

Ré, P. \& Meneses, I. (2009). Early stages of marine fishes occurring in the Iberian Peninsula. IMAR/University Lisboa: IPIMAR.

Sameoto, D.D. (1984). Environmental factors influencing diurnal distribution of zooplankton and ichthyoplankton. Journal of Plankton Research, 6 (5): 767-792.

Spooner, G.M. (1931). Some observations on schooling in fish. New Series, 17 (2): 421448 . 